\title{
Biological Activities and Contents of Scopolin and Scopoletin in Sweetpotato Clones
}

\author{
Joseph K. Peterson', Howard F. Harrison' ${ }^{2}$, and D. Michael Jackson ${ }^{3}$ \\ U.S. Vegetable Laboratory, U.S. Department of Agriculture, Agricultural \\ Research Service, 2875 Savannah Highway, Charleston, SC 29414-5334
}

\author{
Maurice E. Snook ${ }^{4}$ \\ Russell Research Center, University of Georgia, Athens, GA 30604-5677
}

Additional index words. Plutella xylostella, diamondback moth, Fusarium oxysporum, Fusarium solani, Lasiodiplodia theobromae, Rhizopus stolonifer, Ipomoea batatas, allelopathy, fungicidal activity, antibiosis

\begin{abstract}
Periderm and cortex tissues of 14 genetically diverse sweetpotato [Ipomoea batatas (L.) Lam.] clones were grown under low stress conditions and analyzed for their content of scopoletin ((7-hydroxy-6-methoxycoumarin) and scopolin (7-glucosylscopoletin). A wide range of concentrations of both compounds was found in both tissues. The two compounds were tested in vitro for their biological activity (concentration-activity relationships) using several bioassays: germination of proso-millet (Panicum milliaceum L.) seed; mycelial growth of the sweetpotato fungal pathogens $F$ usarium oxysporum Schlecht. f. sp. batatas (Wollenw.) Snyd. \& Hans, F. solani (Sacc.) Mart., Lasiodiplodia theobromae (Pat.) Griffon \& Maubl., and Rhizopus stolonifer (Ehr. ex Fr.) Lind; and growth and mortality of diamondback moth [Plutella xylostella $(\mathrm{L})$.$] larvae on artificial diet. The glycoside scopolin$ showed little activity, except moderate inhibition of $F$. oxysporum. The aglycone scopoletin inhibited seed germination and larval growth; however, at much higher concentrations than were measured in the tissues. Mycelial growth of the four pathogenic fungi, however, was inhibited at concentrations occurring in some sweetpotato clones.
\end{abstract}

The phenolic compound scopoletin was discovered by Gentner (1928), who observed strong blue fluorescence when germinating seeds or seedlings were observed under ultraviolet light. The compound was identified by Best (1944) as 7-hydroxy-6-methoxy coumarin. Scopoletin and its glycoside scopolin are ubiquitous in the plant kingdom. They occur in low concentrations in the vascular systems of healthy plants (Andreae, 1948; Chou and Waller, 1980; Parker, 1977; Santamour and Riedel, 1994). Scopoletin accumulates around necrotic lesions of virus-infected plants and is subsequently transported to the vascular bundles (Best, 1936). Various experiments showed that scopoletin accumulates as a result of injury, and the amount produced is dependent on the type of injury and the amount of compound normally present in unaffected plants (constitutive levels) (Best, 1936). Martin (1957), observing exudation by oat roots, concluded that favorable culture criteria result in low release rates and that exudation rates of scopoletin provide a sensitive indicator of biotic and abiotic stresses. For example, scopoletin accumulates 10 times higher in tobacco plants infected with Pseudomanas solanacearum than in healthy plants (Se-

Received for publication 24 Apr. 2002. Accepted for publication 25 Nov. 2002.

${ }^{1}$ Research Plant Physiologist, retired.

${ }^{2}$ Research Agronomist. E-mail address: hharrison @ saa.ars.usda.gov

${ }^{3}$ Research Entomologist.

${ }^{4}$ Research Chemist. queira and Kelman, 1962). A relatively high yield of this coumarin derivative is obtained from young tobacco plants that are decapitated. The yields increase even further when the plants are subsequently infected with tomato spotted wilt virus. It is noteworthy that after these treatments the compound accumulates in the roots (Best, 1948). Scopoletin was detected in sweetpotato storage roots infected with black rot fungus (Hyodo et al., 1969; Uritani and Hoshiya, 1953). In the roots, production of scopoletin is stimulated by toxic chemicals, such as mercuric chloride and monoiodoacetate (Uritani et al., 1960), sweetpotato weevil damage (Akazawa and Uritani, 1960), larval components of the sweetpotato weevil (Uritani et al., 1975), cellfree fungal extracts (Kim and Uritani, 1974), and nematodes (Gaspasin et al., 1988). In the early literature, the glycoside scopolin is not mentioned. Considering that aqueous extractions often were performed, the sugar moiety may have been removed by plant-derived $\beta$ glucosidase. When under fungal attack, glycosidases from the fungal parasite may break the glycosidic bond (Pridham, 1960; Sproston, 1957). In tobacco the concentration of both scopolin and scopoletin increase when attacked by a number of fungal pathogens (Reuveni and Cohen, 1978; Sequira and Kelman, 1962; Snook et al., 1991) or tobacco mosaic virus. When tobacco callus is inoculated with Thielaviopsis basicola, however, only scopolin increases. The concentration of scopoletin remains the same (Gasser et al., 1988). The exact roles of scopolin and scopoletin in plant-pathogen interactions is not clear (Ahl Goy, 1993). The glycoside scopolin-being inactive in most bioassays, including those reported here-may well be the common modality for transport and a nontoxic storage form of scopoletin. This would follow a general pattern for plant-produced toxic compounds, including phenolics (Farkas and Kiraly, 1962). Metabolism and some roles of scopoletin and scopolin in plant disease were discussed by the last-mentioned authors as well as by Goodman et al. (1967). Scopoletin also inhibits plant growth and is released by living roots or dead tissues. Its allelopathic potential was shown by several researchers (Datta and Dasmahapatra, 1984; Eberhardt and Martin, 1957; Einhellig et al., 1970; Faye and Duke, 1977; Martin and Rademacher, 1960; Shimomura et al., 1982).

Our objectives were to determine the variability in scopolin and scopoletin contents of the periderm and cortex tissues of 14 genetically diverse clones. The effects of scopolin and scopoletin on seed germination, insect larval growth and survival, and mycelial growth of four sweetpotato fungal pathogens were determined quantitatively using in vitro bioassays in order to establish potential biological activities for these defense chemicals.

\section{Materials and Methods}

Seed germination assays. The effect of scopolin and scopoletin on proso millet seed germination was tested utilizing a previously described experiment (Peterson and Harrison, 1991) Scopolin and scopoletin dissolved in methanol were added to filter papers in $10-\mathrm{cm}$ petri dishes. After the methanol was fully evaporated, each dish received $5 \mathrm{~mL}$ purified water. The concentrations tested were 150,300, 500, 700 , and $900 \mu \mathrm{g} \cdot \mathrm{mL}^{-1}$ for scopoletin and 200 , 400 , and $800 \mu \mathrm{g} \cdot \mathrm{mL}^{-1}$ for scopolin. The dishes received 100 seed each and were subsequently incubated at $22 \pm 0.5^{\circ} \mathrm{C}$ for $42 \mathrm{~h}$. The criterion for germination was radicle length equal to or greater than the diameter of the seed. The data for the 10 replicates per experiment were averaged and the four repetitions of the experiments served as replicates for analysis of variance in a completely random design. Sigmoidal regression lines best fitted to the data were determined utilizing the Regression Wizard program of SigmaPlot (SPSS, Chicago).

Fungal assay procedures. The effect of scopolin and scopoletin on four sweetpotato root pathogenic fungi, Fusarium oxysporum f.sp. batatas (FOB), Fusarium solani (FS), Lasiodiplodia theobromae (LT), and Rhizopus stolonifer (RS), was determined using a previously described bioassay experiment (Harrison etal., 2001). Test concentrations were $25,50,100,200,400 \mu \mathrm{g} \cdot \mathrm{mL}^{-1}$ potato dextrose agar medium (PDA) (BBL Potato Dextrose Agar, Beckton Dickenson Microbiology Systems, Cockeysville, Md.) for scopoletin and $200,400,800,1000$, and $1400 \mu \mathrm{g} \cdot \mathrm{mL}^{-1}$ for scopolin. Methanolic solutions of scopoletin or scopolin were pipetted into 50 -mL beakers; the methanol was evaporated completely and warm PDA was poured into the beakers. After vigorous stirring, $1.5-\mathrm{mL}$ aliquots of test solu- 
tions were pipetted into $35 \times 10 \mathrm{~mm}$ petri dishes. After cooling, segments of mycelium $\approx 1-\mathrm{mm}$ diameter were transferred to the center of the petri dishes, placed in an incubator in the dark at $25^{\circ} \mathrm{C}$ and incubated for $60,60,40$, and 18 $\mathrm{h}$ for FOB, FS, LT, and RS, respectively. At the end of the incubation period, the diameter of the fungal colonies was measured with a caliper. The experiments were replicated $5 x$ and all experiments were repeated $4 \times$. The experiments were arranged in a completely random design and treatment means from the four experiments were used as replicates in an analysis of variance (ANOVA) for a completely random design. Sigmoidal regression lines were generated as mentioned before.

Insect rearing. The diamondback moth colony originated from the Geneva 88 Colony, which was started in 1988 and has been maintained continuously since then (Shelton et al., 1991). A starter colony has been maintained continuously in our laboratory since Jan. 1997. The insects were reared on a Multiple Species Diet (Southland Products, Lake Village, Ark.), using techniques described by Shelton et al. (1991) and adapted for this study (Jackson and Peterson, 2000).

Insect bioassays. An aliquot of scopolin or scopoletin for each treatment concentration was weighed into a small polyethylene cup (hollow stopper) and dissolved into a minimum amount of purified methanol. The methanol was evaporated, leaving a film of the test chemical on the cup walls. This procedure facilitates dissolution of the chemicals. About $3 \mathrm{~mL}$ of warm $\left(52^{\circ} \mathrm{C}\right)$ diet was added to a cup and the material was stirred vigorously for 2 min. After cooling for at least $30 \mathrm{~min}$, the cups were weighed to determine the actual amount of diet in the cup since it was impossible to pipet the diet accurately. The specific weight of the diet was determined gravimetrically $8 \times$. Subsequently, $0.3 \mathrm{~mL}$ diet with test chemical was packed into the tip of a $1.5-\mathrm{mL}$ microcentrifuge tube. Air was excluded as much as possible to slow down oxidation of diet components. Each tube received one neonatal larva, taken from a cohort. The tubes were closed with a lid that had a small hole in it to prevent condensation. Incubation was at $25 \pm$ $0.5^{\circ} \mathrm{C}$, photo/scoto periods of $14: 10 \mathrm{~h}$, and $\approx 50 \%$ relative humidity. After $7 \mathrm{~d}$, mortality was determined and live larvae were weighed. Each concentration treatment was replicated $10 \times$ and controls (concentration $=0$ ) were replicated $20 \times$. The nominal concentrations for scopoletin were: $625,1250,2500,5000$, and $10,000 \mu \mathrm{g} \cdot \mathrm{mL}^{-1}$ and for scopolin were: $313,625,1250$, and $2500 \mu \mathrm{g} \cdot \mathrm{mL}^{-1}$. These numbers were corrected for the deviation of the diet volumes, which were $3.0 \mathrm{mLnominally.}$ Scopoletin experiments were repeated $5 \times$, and scopolin experiments were repeated $3 \times$.

Culture and tissue manipulation of sweetpotato clones. The 14 sweetpotato cultivars and breeding clones ('Beauregard', 'Carolina Bunch', 'Excel', 'Jewel', 'PI 399163', 'Regal', 'SC1149-19', 'Sulfur', 'Sumor', 'Tinian', 'W-274', 'TIS 80/637', 'TIS 9101', and 'TIS 70357') used for quantitative analyses of scopolin and scopoletin were genetically diverse and most have been used in previous research. (Harrison et al., 2001; Peterson et al., 1999). Sweetpotatoes were grown in Charleston, S.C., during 2000 using standard cultural practices. Irrigation and appropriate pest control measures were used to minimize physical and biological stress. At the end of the growing season, the marketable-sized storage roots were collected and processed without curing.

Roots were gently washed under flowing water and air dried. Periderm tissue was removed with a scalpel, taking care to avoid damaged tissue. The skin was dried at $55^{\circ} \mathrm{C}$ and ground to a powder with mortar and pestle, and liquid nitrogen used to keep the tissue frozen, then re-dried, placed in vials, and stored at $-20{ }^{\circ} \mathrm{C}$. The thickness of the cortex tissue was measured with calipers; the tissue was removed and freeze-dried. Subsequently, the cortex tissue was ground and stored at $-20^{\circ} \mathrm{C}$.

Periderm "thickness," expressed as dry weight in $\mathrm{mg} \cdot \mathrm{cm}^{-2}$, was determined as follows: five circles per root were delineated using a cork borer (16.3-mm diameter). The skin was scraped off within the borders of the circles and the tissue was dried at $55^{\circ} \mathrm{C}$ and weighed. This procedure was repeated $5 \times$ per clone.

Cortex moisture content was determined gravimetrically by pre-weighing samples, drying at $55^{\circ} \mathrm{C}$ until constant weight, and reweighing. Moisture content was determined $4 \times$ per clone. Five marketable storage roots of each clone were selected for analysis. Periderm density, cortex thickness, and percent dry matter of each root were determined separately; these data were subjected to analysis of variance using a completely random design. Tissues from the roots were combined and an aliquot was removed for chemical analyses.

Isolation of scopolin. Scopolin was isolated from freeze-dried flue-cured tobacco roots, since it is not commercially available. Detailed isolation protocols were described by Snook et al. (1992). Briefly, a methanolic extract was chromatographed on a silicic acid column (Mallinkrodt 100 mesh, activated at $150{ }^{\circ} \mathrm{C}, 16 \mathrm{~h}$ ) using a step gradient of a number of solvent mixtures. The proper fraction containing scopolin was re-chromatographed on a preparative reverse-phase column (Waters Prep-Pak 500 material) and eluted isocratically with $35 \% \mathrm{MeOH}-\mathrm{H}_{2} \mathrm{O}$ ). This procedure yielded scopolin with a purity greater than 95\%. However, preliminary experiments using seed germination assays showed unexpectedly high inhibition. The scopolin was redissolved in methanol, an equal amount of acetonitrile was added, and the solution was evaporated to dryness. This procedure apparently removed tightly bound water. Scopolin could now be crystallized from $\mathrm{MeOH}$. High-performance liquid chromatography (HPLC) procedures, the same as used for quantitative analyses, and described below, were used to check for purity. Purity of scopolin obtained in this manner was estimated to be $>99 \%$.

The aglycone scopoletin was purchased from Sigma (St. Louis, Mo.) and used as received (purity $99 \%$ or greater).

HPLC analysis of scopolin and scopoletin.
Samples (200 mg) were weighed into $13 \times 100$ $\mathrm{mm}$ teflon-lined, screw-capped test tubes and $2.0 \mathrm{~mL}$ of methanol added, containing $0.08 \mathrm{mg}$ of crysin (recrystallized from amyl alcohol) as internal standard. The test tubes were ultrasonicated for $20 \mathrm{~min}$ (ice-cooled), centrifuged, and filtered through $0.45-\mu \mathrm{m}$ Nylon 66 membrane filters into autoinjector vials. Aliquots of $20 \mu \mathrm{L}$ of the solution were analyzed by reversed-phase HPLC using a $\mathrm{H}_{2} \mathrm{O} / \mathrm{MeOH}$ linear gradient from $10 \%$ to $90 \% \mathrm{MeOH}$ in $35 \mathrm{~min}$, a flow rate of 1 $\mathrm{mL} \cdot \mathrm{min}^{-1}$ and detection at $340 \mathrm{~nm}$. Each solvent contained $0.1 \% \mathrm{H}_{3} \mathrm{PO}_{4}$. Response factors were determined with pure authentic compounds. Quantitation was based on the internal standard (chrysin) and peak identification was based on co-chromatography of authentic compounds (spiking) and spectral analysis.

\section{Results}

Effects on germination of prosomillet seed. The concentration response curve for scopoletin showed a pattern generally seen for allelopathogens (Fig. 1). The minimum inhibitory concentration (MIC) was $\approx 300$ $\mu \mathrm{g} \cdot \mathrm{mL}^{-1}$ scopoletin; below this concentration stimulation was apparent. Fifty percent inhibition $\left(\mathrm{IC}_{50}\right.$ ) extrapolated from the regression line was $\approx 610 \mu \mathrm{g} \cdot \mathrm{mL}^{-1}$. The glycoside scopolin was not inhibitory up to $800 \mu \mathrm{g} \cdot \mathrm{mL}^{-1}$, the highest concentration tested.

Effects on mycelial growth of pathogenic fungi. In comparison with the controls, all concentrations of scopoletin inhibited Fusarium oxysporum and Rhyzopus stolonifer, and concentrations of $50 \mu \mathrm{g} \cdot \mathrm{mL}^{-1}$ and higher inhibited Fusarium solani and Lasiodiplodia theobromae (Fig. 2A-D). The $\mathrm{IC}_{50}$ values extrapolated from regression lines were $\approx 190,100,160$, and $120 \mu \mathrm{g} \cdot \mathrm{mL}^{-1}$ for $F$. solani, F. oxysporum, $R$. stolonifer, and L. theobromae, respectively. Fusarium oxysporum was also inhibited by scopolin $\left(\mathrm{IC}_{50} \approx 2000 \mu \mathrm{g} \cdot \mathrm{mL}^{-1}\right)$. Growth of the other three pathogens was not different from the controls at scopolin concentrations up to $2000 \mu \mathrm{g} \cdot \mathrm{mL}^{-1}$ (data not presented).

Effects on total live weight and survival of diamondback larvae. Total live weight, expressed as percent control, showed a sharp decline at scopoletin concentrations $>2500$ $\mu \mathrm{g} \cdot \mathrm{g}^{-1}$ diet after $6 \mathrm{~d}$ (Fig. 3A). The extrapolated $\mathrm{IC}_{50}$ was $\approx 4100 \mu \mathrm{g} \cdot \mathrm{g}^{-1}$ diet. Survival was negatively correlated with scopoletin concentrations. After $6 \mathrm{~d}$ of exposure, $50 \%$ of the larvae died $\left(\mathrm{LD}_{50}\right)$ when the concentration of scopoletin was $\approx 8300 \mu \mathrm{g} \cdot \mathrm{mL}^{-1}$ diet (Fig. 3B). Scopolin was bioassayed at concentrations up to $2500 \mu \mathrm{g} \cdot \mathrm{g}^{-1}$ diet, the highest concentration that remained in solution. This concentration is $25 \times$ higher than the highest concentration we found in sweetpotato storage roots. No effects were observed on larval survival or on total live weight after $6 \mathrm{~d}$.

Concentrations of scopolin and scopoletin in periderm and cortex tissues of 14 sweetpotato clones. The concentrations of scopoletin ranged from 0 to $103 \mu \mathrm{g} \cdot \mathrm{g}^{-1}$ dry weight of periderm and from 5.8 to $35.6 \mu \mathrm{g} \cdot \mathrm{g}^{-1}$ dry weight of cortex tissue (Table 1). Scopolin concentrations ranged between 50.7 to 773 
$\mu \mathrm{g} \cdot \mathrm{g}^{-1}$ dry periderm and between 98.9 and 588 $\mu \mathrm{g} \cdot \mathrm{g}^{-1}$ dry cortex tissue. In addition, periderm "densities" $\left(\mathrm{mg} \cdot \mathrm{cm}^{-2}\right)$, thickness of the cortex, water content, and contents of scopolin and scopoletin on a fresh weight basis are listed in Table 1 .

\section{Discussion}

Earlier research showed that insect resistance factors occurred primarily in the periderm and cortex tissues of sweetpotatoes (Peterson and Schalk, 1990; Schalk et al., 1986), Stele tissue which comprises most of the storage root played a minimal role, or in some cases none at all. In preliminary experiments with sweetpotato pathogenic fungi we observed the same pattern (unpublished data). We therefore limited the chemical analyses to periderm and cortex tissues. In addition to concentrations of defense chemicals, the thickness of the tissues in which these chemicals occur may play a role, since for example, insects that can survive on stele tissue would have to "consume" their way through the periderm and cortex. Also, when considering allelopathic suppression of weeds, the total amount of active chemicals released would be the most relevant parameter. For these reasons the thickness and moisture content of the cortex and the density of the periderm were measured (Table 1). The water content of the periderm is difficult to determine because the tissue dries rapidly when separated from the root. However, the thickness expressed as $\mathrm{mg} \cdot \mathrm{cm}^{-2}$ dry periderm tissue (Table 1 ) allows the calculation of amount of chemical on a root surface area basis. The bioassays employed in the research reported here are similar to those used previously (Harrison et al., 2001; Jackson and Peterson, 2000; Peterson et al.,1998, 1999, 2002) allowing estimation of relative contributions the various chemical components may make in specific defense roles.

The chemical data presented in Table 1 show concentrations which may be expected under low stress conditions. It is not known what levels may be attained under conditions of specific high stresses. These parameters are under current investigation. If, however, constitutive levels reflect inducible ones (Best, 1936; Martin, 1957), Table 1 shows that large differences in inducible concentrations can be expected and breeding potentials may be favorable. For breeding purposes, data for the relative concentrations of defense chemicals are useful and the use of the same clones in our research allows comparisons of relative contributions these chemicals may make. The absence of scopoletin in the periderm of most clones suggest that this compound is synthesized in the cortex.

An additional complication arises when considering the roles of scopolin. The results

Fig. 2. (A-D) Growth of sweetpotato root rotting fungi, Fusarium solani, Lasiodiplodia theobromae, and Rhyzopus stolonifer, in response to scopoletin and Fusarium oxysporum in response to scopoletin and scopolin in potato dextrose agar medium in a petri dish bioassay. Vertical bars represent standard errors of the means.

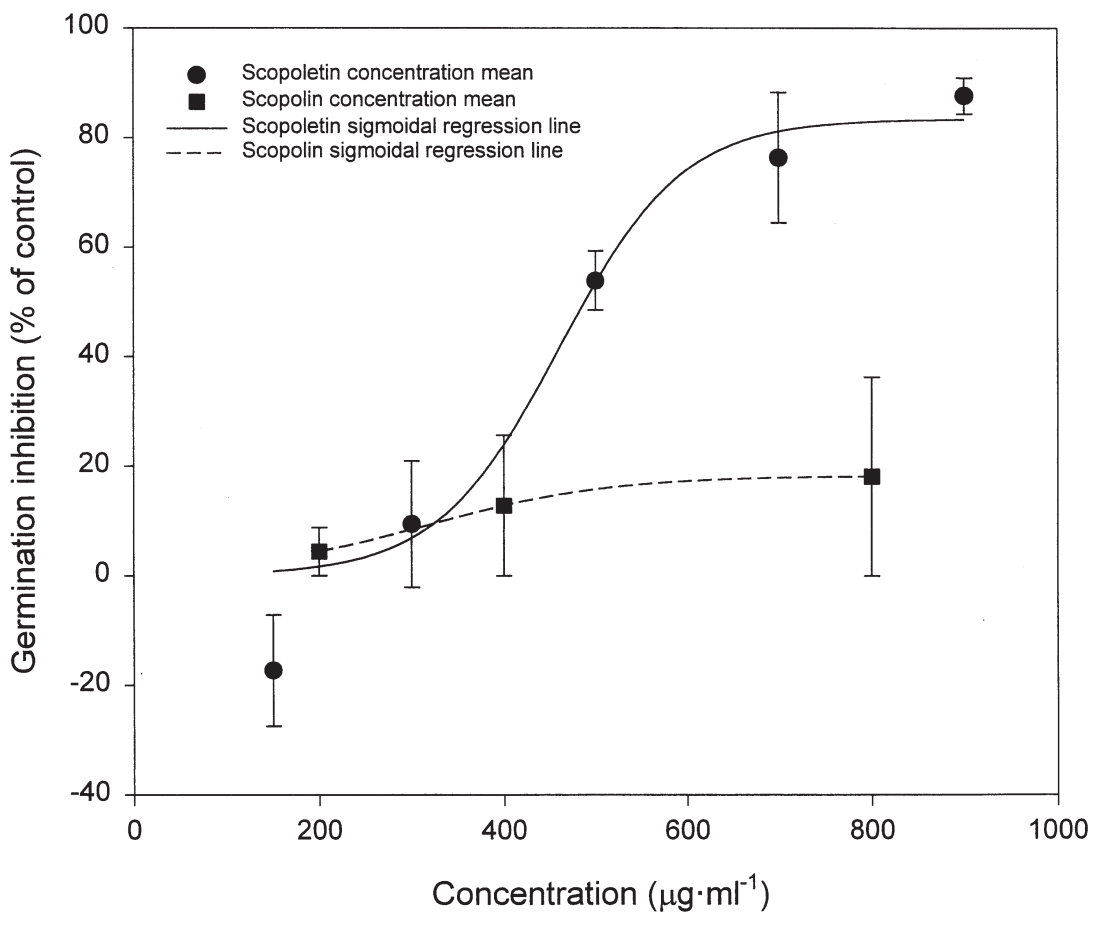

Fig. 1. Inhibition of prosomillet seed germination by scopoletin and scopolin in a petri dish bioassay. Vertical bars represent standard errors of the means.


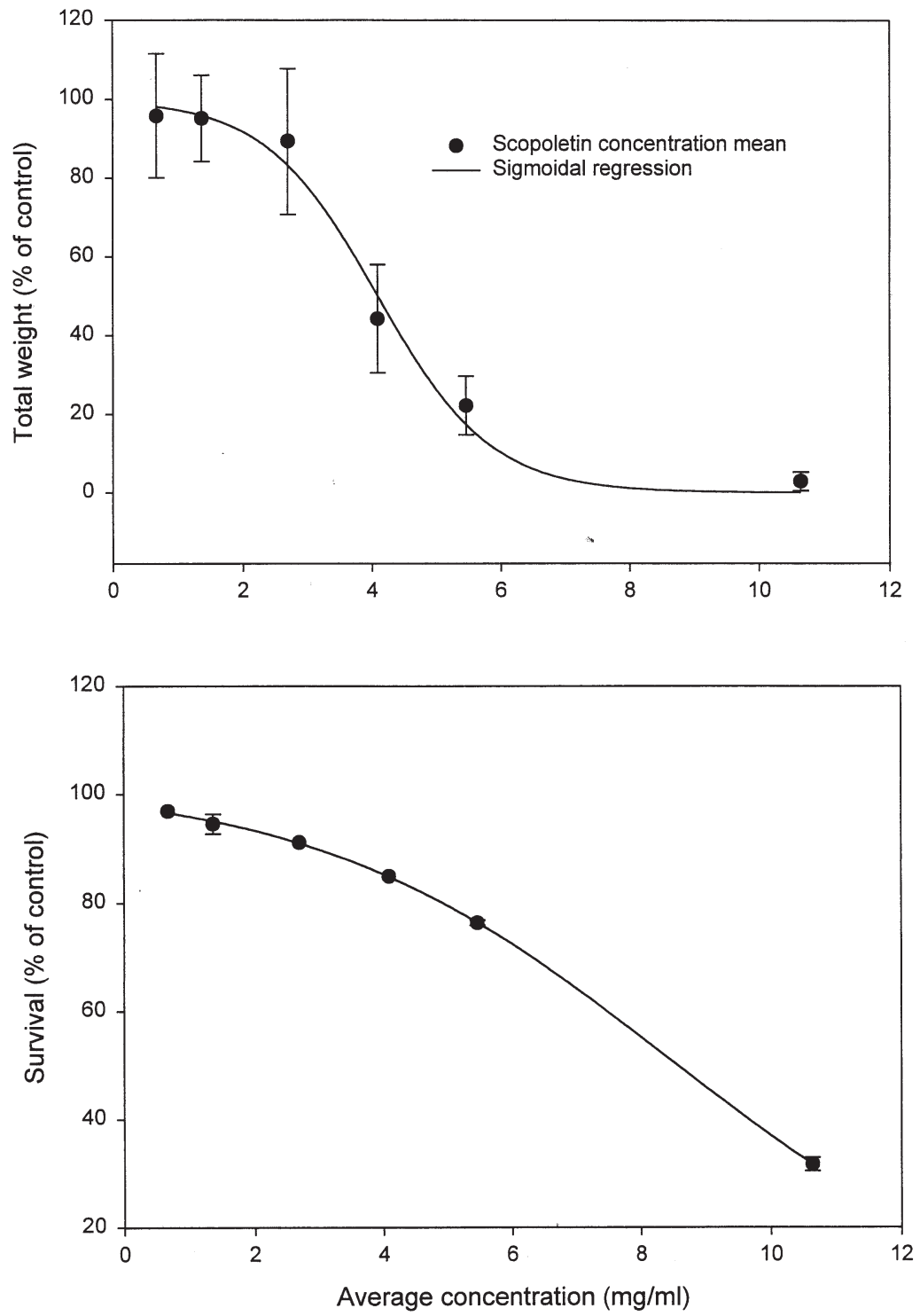

Fig. 3. (A-B) Growth and mortality of diamondback moth larvae in response to scopoletin in an artificial diet. Vertical bars represent standard errors of the means. of bioassays reported here show little if any effect at relatively high concentrations. Snook et al. (1992) showed that glycosilated coumarins, including scopolin, did not inhibit the growth of Phytophthora parasitica var. nicotianae; the aglycones, however, were active. Most phenolics in plants occur in the water-soluble glycosidic or other conjugated form (Harborne, 1977) and are as such not harmful to the tissues in which they occur (Stenlid, 1970). The glycosidic linkage may be broken in the plant upon leaf senescence or prior to excretion(Harborne, 1977 ) or by $\beta$-glucosidase activity produced by a fungal agent (Oku, 1959). This may explain our observation that scopolin was active against F. oxysporum.

Scopoletin inhibited proso-millet seed germination only slightly $\left(\mathrm{IC}_{50} \approx 610 \mu \mathrm{g} \cdot \mathrm{mL}^{-1}\right.$ ) as compared to resin glycosides from the periderm $\left(\mathrm{IC}_{50} \approx 11 \mu \mathrm{g} \cdot \mathrm{mL}^{-1}\right.$; Peterson and Harrison, 1991). It is not expected that scopoletin and its glycoside, when released from decaying sweetpotato tissue in the field, play significant roles in suppressing surrounding weeds.

Previous research showed that sweetpotatoes contain various chemical components that inhibit mycelial growth of the fungi used in this study (Harrison et al., 2001). The data show that the constitutive levels of scopoletin, on a fresh weight basis, are low (Table 1). However, the combined concentrations of scopolin and scopoletin exceed the $\mathrm{IC}_{50}$ values for scopoletin (Fig 2) in a few clones. Considering that the reported concentrations are constitutive, it is possible that they are important in defense against fungal pathogens if stress induces the accumulation of higher levels.

The concentration-activity plot for total live weight of diamondback larvae exposed to scopoletin shows a strong negative correlation (Fig. 3); however, the concentrations needed for effective antibiosis are above $2000 \mu \mathrm{g} \cdot \mathrm{mL}^{-1}$. It should be noted that sublethal dosages may have chronic negative effects, as was shown for sweetpotato resin glycosides (Jackson and Peterson, 2000).

Table 1. Content of scopolin and scopoletin in periderm and cortex tissue, density of periderm, and thickness and dry matter content of cortex tissues of 14 sweetpotato clones.

\begin{tabular}{|c|c|c|c|c|c|c|c|c|c|}
\hline \multirow[b]{3}{*}{ Clone } & \multicolumn{3}{|c|}{ Periderm } & \multirow{3}{*}{$\begin{array}{c}\text { Thickness } \\
\text { (mm) }\end{array}$} & \multirow{3}{*}{$\begin{array}{l}\mathrm{DM}^{\mathrm{y}} \\
(\%)\end{array}$} & \multicolumn{4}{|c|}{ Cortex } \\
\hline & \multirow{2}{*}{$\begin{array}{c}\text { Density } \\
\left(\mathrm{mg} \cdot \mathrm{cm}^{-2}\right)\end{array}$} & \multirow{2}{*}{$\begin{array}{c}\text { Scopolin } \\
\text { content } \\
\left(\mu \mathrm{g} \cdot \mathrm{g}^{-1} \mathrm{DW}\right)\end{array}$} & \multirow{2}{*}{$\begin{array}{c}\text { Scopoletin } \\
\text { content } \\
\left(\mu \mathrm{g} \cdot \mathrm{g}^{-1} \mathrm{DW}\right)\end{array}$} & & & \multicolumn{2}{|c|}{ Scopolin } & \multicolumn{2}{|c|}{ Scopoletin } \\
\hline & & & & & & $\overline{\left(\mu \mathrm{g} \cdot \mathrm{g}^{-1} \mathrm{DW}\right)}$ & $\overline{\left(\mu \mathrm{g} \cdot \mathrm{g}^{-1} \mathrm{FW}\right)}$ & $\overline{\left(\mu \mathrm{g} \cdot \mathrm{g}^{-1} \mathrm{DW}\right)}$ & $\left(\mu \mathrm{g} \cdot \mathrm{g}^{-1} \mathrm{FW}\right)$ \\
\hline Beauregard & 2.01 & 138.0 & 0.0 & 3.36 & 13.41 & 103.61 & 13.86 & 6.51 & 0.87 \\
\hline Carolina Bunch & 0.44 & 73.2 & 0.0 & 3.20 & 12.03 & 234.70 & 28.22 & 18.88 & 2.27 \\
\hline Excel & 2.76 & 138.0 & 0.0 & 3.27 & 14.28 & 302.73 & 43.23 & 12.66 & 1.81 \\
\hline Jewel & 2.13 & 82.2 & 0.0 & 3.82 & 16.57 & 143.97 & 23.96 & 13.16 & 2.19 \\
\hline PI 399163 & 2.08 & 773.0 & 0.0 & 3.65 & 32.87 & 98.93 & 32.43 & 12.69 & 4.16 \\
\hline Regal & 1.19 & 571.0 & 0.0 & 5.56 & 16.69 & 587.75 & 98.18 & 28.23 & 4.72 \\
\hline SC1149-19 & 1.97 & 50.7 & 51.9 & 4.34 & 17.56 & 96.42 & 16.95 & 10.65 & 1.87 \\
\hline Sulfur & 1.58 & 93.3 & 103.0 & 3.47 & 19.46 & 93.10 & 18.14 & 9.13 & 1.78 \\
\hline Sumor & 2.22 & 110.0 & 0.0 & 4.45 & 19.36 & 76.73 & 14.86 & 5.81 & 1.12 \\
\hline Tinian & 2.59 & 353.0 & 0.0 & 2.96 & 18.82 & 446.20 & 97.86 & 32.02 & 7.02 \\
\hline W 274 & 0.39 & 179.0 & 0.0 & 4.68 & 21.48 & 109.05 & 21.19 & 21.27 & 4.13 \\
\hline TIS 80637 & 1.55 & 334.0 & 0.0 & 4.95 & 12.78 & 182.18 & 23.29 & 9.09 & 1.08 \\
\hline TIS 9101 & 2.48 & 77.6 & 0.0 & 4.13 & 23.47 & 157.70 & 37.03 & 25.21 & 5.92 \\
\hline TIS 70357 & 1.99 & 112.0 & 80.6 & 3.38 & 18.40 & 132.57 & 30.52 & 35.59 & 8.19 \\
\hline $\operatorname{LSD}_{0.05}{ }^{\mathrm{x}}$ & 0.22 & --- & --- & 0.21 & 2.10 & --- & --- & & \\
\hline
\end{tabular}

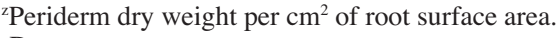

${ }^{y}$ Dry matter.

${ }^{\mathrm{x}} \mathrm{LSD}_{0.05}$ for comparing means within a column. 
In conclusion, constitutive levels of scopolin and scopoletin in some sweetpotato germplasm sources were adequate to interfere in vitro with mycelial growth of $F$. oxysporum, $F$. solani, L. theobromae, and $R$. stolonifer. Scopoletin inhibited germination of prosomillet seed and displayed antibiosis against diamondback larvae but at concentrations higher than the constitutive levels occurring in the 14 clones analyzed. We propose that cortex scopolin and scopoletin concentrations may be useful as quantitative chemical markers for sweetpotato genotypes with disease resistance.

\section{Literature Cited}

Ahl Goy, P., H. Signer, R. Reist, R. Aichholz, W. Blum, E. Schmidt, and H. Kessman. 1993. Accumulation of scopoletin is associated with the high disease resistance of the hybrid Nicotiana glutinosa $\times$ Nicotiana debneyi. Planta 19: 200-206.

Akazawa, T., I. Uritani, and H. Kubota. 1960 Isolation of ipomeamarone and two coumarin derivatives from sweetpotato roots injured by the weevil, Cylas formicarius elegantulus. Arch. Biochem. Biophys. 88:150-156.

Andreae, W.A. 1948. The isolation of a blue fluorescent compound scopoletin, from green mountain potato tubers, infected with leaf roll virus. Can. J. Res. 26:31-34.

Best, R.J. 1936. Studies on a fluorescent substance present in plants. 1. Production of the substance as a result of virus infection and some applications of the phenomenon. Austral. J. Expt. Biol. Med. Sci. 14:199-213.

Best, R.J. 1944. Studies on a fluorescent substance present in plants. 2. Isolation of the substance in a pure state and its identification as 6-methoxy7-hydroxy 1:2 benzo-pyrone. Austral. J. Expt. Biol. Med. Sci 22:251-255.

Best, R.J. 1948. Studies on a fluorescent substance present in plants. 3. The distribution of scopoletin in tobacco plants and some hypothesis on its part in metabolism. Austral. J. Expt. Biol. Med. Sci. 26:225-229.

Chou, C-H. and G.R. Waller. 1980. Possible allelopathic constituents of Coffea arabica. J. Chem. Ecol. 6:643-653.

Datta, S.C. and S. Dasmahapatra. 1984. Allelopathy in two legumes: Inhibition of mustard (Brassica) germination and seedling growth. Comp. Physiol. Ecol. 4:285-289.

Eberhardt, F. and P. Martin. 1957. Das Problem der Wurzelausscheidungen und seine Bedeutung für die gegenseitige Beeinflüssung höherer Pflanzen. Z.f. Pflkrankh. u. Pfl. Schutz 64:193-205.

Einhellig, F.A., E.L. Rice, P.G. Risser, and S.H. Wender. 1970. Effects of scopoletin on growth, $\mathrm{CO}_{2}$ exchange rates, and concentration of scopoletin, scopolin, and chlorogenic acids in tobacco, sunflower, and pigweed. Bul. Torrey Bot. Club 97:22-23.

Farkas, G.L. and Z. Király. 1962. Role of phenolic compounds in the physiology of plant diseases and disease resistance. Phytopathol. Z. 44: 105-150.

Faye, P.K. and W.B. Duke. 1977. An assessment of allelopathic potential in Avena germplasm. Weed Sci. 25:224-228.

Gapasin, R.M., R.B. Valdez, and E.M.T. Mendoza. 1988. Phenolics involvement in sweetpotato resistance to Meloidogyne incognita and $M$. Javanica. Ann. Trop. Res. 10:63-73.

Gasser, R., H. Kern, and G. Défago, 1988. Scopolin, a biochemical marker for resistance to Thielaviopsis basicola in callus and crown-gall tissue cultures of tobacco. J. Phytopathol. 123: $115-123$.

Gentner, G. 1928. Über die Verwendbarkeit von ultravioletten Strahlen bei der Samenprüfung. Prak. B1. Pflanzenbau u. Pflanzenschutz 6:166-172.

Goodman, R.N., Z. Király, and M. Zaitlin. 1967. Phenol metabolism, chap. 6. In: The biochemistry and physiology of infectious plant disease. Van Nostrand, Princeton, N.J.

Harborne, J.B. 1977. Variations in and functional significance of phenolic conjugation in plants. In: T. Swain, J.B. Harborne, and C.F. van Sumere (eds.). Recent advances in phytochemistry of plant phenolics. Vol. 12, chap. 14. Academic Press, London.

Harrison, H.F., J.K. Peterson, C.A. Clark, and M.E. Snook. 2001. Sweetpotato periderm components inhibit in vitro growth of root rotting fungi. HortScience 36:927-930.

Hyodo, H., I. Uritani, and S. Akai. 1969. Production of furanoterpenoids and other compounds in sweetpotato root tissue in response to infection by various isolates of Ceratocystis fimbriata. Phytopathol. Z. 65:332-340.

Jackson, D.M. and J.K. Peterson. 2000. Sublethal effects of resin glycosides from the periderm of sweetpotato storage roots on Plutella xylostella (Lepidoptera: Plutellidae). J. Econ. Entom. 93: 389-393.

Kim, W.K. and I. Uritani. 1974. Fungal extracts that induce phytoalexins in sweetpotato roots. Plant Cell Physiol. 15:1093-1098.

Martin, P. 1957. Die Abgabe von organischen Verbindungen, insbesondere von Scopoletin, aus den Keimwurzeln des Hafers. Z. Botanik 45:475-506.

Martin, P. and B. Rademacher. 1960. Studies on the mutual influences of weeds and crops. Br. Ecol. Soc. Symp. 1:143-152.

Oku, H. 1959. Biochemical studies on Cochliobolus miyabeanus: V. $\beta$-Glucosidase activity on the fungus and the effect of phenolglucoside on the mycelial growth. Ann. Rpt. Takamine Lab. 11: 190-192. (From: Harborne, 1977.)

Parker, J. 1977. Phenolics in black oak bark and leaves. J. Chem. Ecol. 3:489-496.

Peterson, J.K. and H.F. Harrison, Jr. 1991. Isolation of substance from sweetpotato (Ipomoea batatas) that inhibits seed germination. J. Chem. Ecol. 17:943-951.

Peterson, J.K., H.F. Harrison, and A.E. Muckenfuss. 1998. Sweetpotato [Ipomoea batatas (L.) Lam.] resin glycosides: Evidence of antibiosis effects in the diamondback moth Plutella xylostella L. (Lepidoptera: Plutellidae). Allelopathy J. 5:43-52.

Peterson, J.K., H.F. Harrison, and M.E. Snook. 1999. Comparison of three parameters for estimation of allelopathic potential in sweetpotato [Ipomoea batatas (L.) Lam.] germplasm. Allelopathy J. 6:201-208
Peterson, J.K., H.F. Harrison, and M.E. Snook. 2002. Bioassay guided isolation of seed germination inhibitors from sweetpotato [Ipomoea batatas (L.) Lam.] cortex tissue. Allelopathy J. 9:177-186.

Peterson, J.K. and J.M. Schalk. 1990. Resistance factors against Diabrotica balteata Le Conte in the periderm of sweetpotato [Ipomoea batatas (L). Lam]. IOBC/WPRS/Eucarpia, Bul. XIII (6)136-139.

Pridham, J.B. 1960. The formation and possible function of phenolic glycosides. In: J.B. Pridham (ed.). Phenolics in plants, in health and disease. Pergamon Press, Oxford.

Reuveni, M. and Y. Cohen, 1978. Growth retardation and changes in phenolic compounds, with special reference to scopoletin in mildewed and ethylene-treated tobacco plants. Physiol. Plant Pathol. 12:179-189.

Santamour, F.S. Jr. and L.G.H. Riedel. 1994. Distribution and inheritance of scopolin and herniarin in some Prunus species. Biochem. Syst. Ecol. 22:197-201.

Schalk, J.M.,A. Jones, and P.D. Dukes. 1986. Factors associated with resistance in recently developed sweetpotato cultivars and germplasm to the banded cucumber beetle, Diabrotica balteata Le Conte. J. Agr. Entomol. 3:329-334.

Sequeira, L. and A. Kelman. 1962. The accumulation of growth substances in plants infected by Pseudomonas solanacearum. Phytopathology 54:1078-1083.

Shelton, A.M., R.J. Cooley, M.K. Kroening, W.T. Wilsey, and S.D. Eigenbrode. 1991. Comparative analysis of two rearing procedures for diamondback moth (Leidoptera:Plutellidae). J. Econ. Sci. 26:17-26.

Shimomura, H., Y. Sashida, H. Nakata, J. Kawasaki, and Y. Ito. 1982. Plant growth regulators from Heracleum lanatum. Phytochemistry 21: 2213-2215.

Snook, M.E., O.T. Chortyk , and A.S. Csinis. 1991. Black shank disease fungus: Inhibition of growth by tobacco root constituents and related compounds. In: P.A. Hedin (ed.). Naturally occurring pest bioregulators (ACS Symp. Ser. 448). Amer. Chem. Soc., Washington, D.C.

Snook, M.E., A.S. Csinis, and O.T. Chortyk. 1992. Inhibition of growth of Phytophthora parasitica var. nicotianae by aromatic acids and coumarins in a laboratory bioassay. J. Chem. Ecol. 18:1287-1297.

Sproston, T. 1957. Studies on the disease resistance of Impatiens balsamina. Phytopathology 47:534.

Stenlid, G. 1970. Flavonoids as inhibitors of the formation of adenosine triphosphate in plant mitochondria. Phytochemistry 9:2251-2256.

Uritani, I. and I. Hoshiya. 1953. Phytopathological chemistry of the black-rotten sweetpotato. Part 6. Isolation of coumarin substances from sweetpotato and their physiology. J. Agr. Chem. Soc. Japan 27:161-164.

Uritani, I., T. Saito, H. Honda, and W.K. Kim. 1975. Induction of furanoterpenoids in sweetpotato roots by the larval components of the sweetpotato weevils. Agr. Biol. Chem. 39:1857-1862.

Uritani, I., M. Uritani, and H. Yamada 1960. Similar metabolic alterations induced in sweetpotato by poisonous chemicals and by Ceratostomella fimbriata. Phytopathology 50:30-34. 